\title{
Analysis of the Reproduction Traits and Milk Yield in Cows from Apuseni Mountains Farms
}

\author{
Ioan $\mathrm{HAN}^{1}$, Otilia BOBIŞ ${ }^{2}$ \\ ${ }^{1}$ Faculty of Animal Science and Biotechnologies, University of Agricultural Sciences and Veterinary \\ Medicine - 400372, Cluj-Napoca, Mănăștur, 3-5, România \\ ${ }^{2}$ Life Science Institute "King Michael I of Romania", University of Agricultural Sciences and Veterinary \\ Medicine - 400372, Cluj-Napoca, Mănăștur, 3-5, România \\ *Author to whom correspondence should be addressed: University of Agricultural Sciences and Veterinary \\ Medicine Cluj-Napoca, Life Science Institute, Manastur, 3-5, 400372, Cluj-Napoca, Romania; E-mail: \\ obobis@usamvcluj.ro; telephone +40264 596384; fax+40264 593792
}

Bulletin UASVM Animal Science and Biotechnologies 76(1)/ 2019

Print ISSN 1843-5262; Electronic ISSN 1843-536X

DOI:10.15835/buasvmcn-asb: 2019.0004

\begin{abstract}
Milk production in cows is influenced by a series of factors with direct or indirect action upon its body. Farms from three counties in Apuseni Mountains (Alba, Bihor and Hunedoara) were monitorized for milk production and other reproductive attributes. Age of first calving, service period, calving interval and natality were the parameters monitorized in the study to determine the reproduction trains in the area of Apuseni Mountains. Analyzing the obtained data regarding the average production of milk, lactation duration in the studied counties, it is found that: on total lactation, the largest production was obtained in Bihor county with $4815.26 \mathrm{~kg}$ (332.6 days), followed by Hunedoara county with $4796.40 \mathrm{~kg}$ (325.6 days) and Alba county with $4528.05 \mathrm{~kg}$ ( 321.4 days). The obtained results, which reflect the current level of milk production in Apuseni Mountain area, show that the studied cows have a real productive potential, the average of the lactation yields as well as its duration, being at the upper limit of the breed, according also to specialized literature data. Breeding activity was found to be good but can be improved. Due to the great importance of reproduction, the economic and productive performance of dairy farms requires careful attention to its planning and management.
\end{abstract}

Keywords: Apuseni Mountains, cows, farms, reproductive attributes.

\section{Introduction}

Successful reproductive management is essential for profitable milk production in dairy farms (Fodor and Ózsvári, 2015). Reproductive indices may give the best informations regarding many breeding problems, connected to milk production or with individual reproduction for dairy cows (Verner et al., 2012).

Milk production factors. The milk production of a cow is influenced by a series of factors with direct or indirect action on its body. In principle, these factors act concurrently and as a function of the stage and time at which the target animal is located during the technological but with a different intensity, both on the quantity of milk and on the quality and chemical composition of the milk. Some factors that influence and condition the individual milk production can be presented schematically according to the direction of action (Table 1).

Onaciu (2013) considers that Bălţata Românească breed is a semiprecocious breed, which achieves full maturity at $4-41 / 2$ years, and reproductive maturity at $17-22$ months. Its 
Table 1. Animal dependent internal factors and technological external factors, influencing individual milk production (Onaciu, 2013)

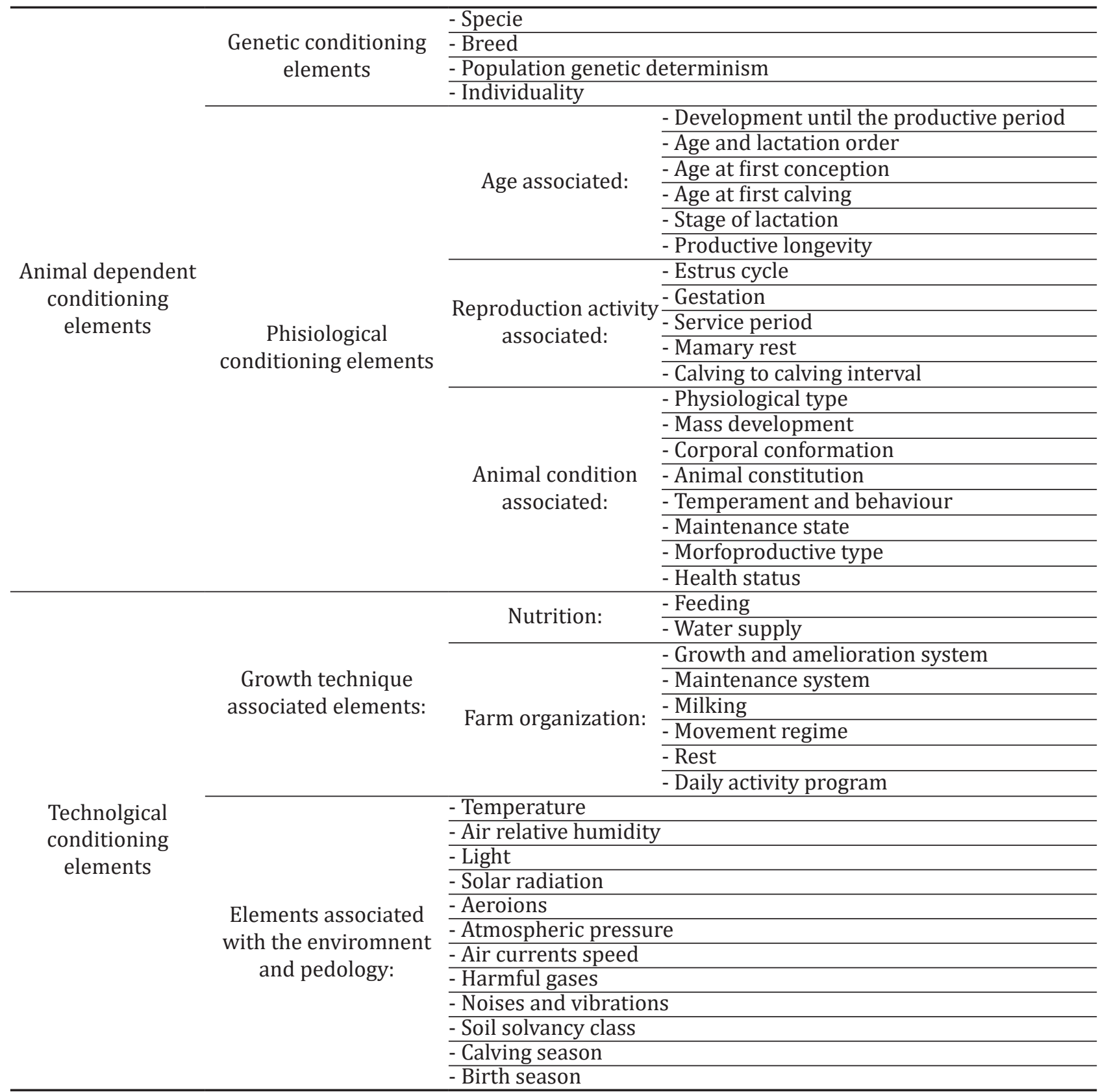

economic life is 8 - 9 lactations, with duration of 270 - 330 days and birth rates of about $85 \%$. Milk production varies between $3000-6500 \mathrm{~kg}$, with $3.6-4.2 \%$ fat. Ujica et al. (2007) considers that, if well maintained, the Bălţată Românească breed produces 3500 - $4000 \mathrm{~kg}$ of milk/lactation, with $3.8 \%$ fat. Acatincăi (2010) also considers that in the Bălţata Românească breed, depending on the conditions of feed and maintenance, milk production varies widely. On average, the production is $3000-3500 \mathrm{~kg}$ milk/lactation, with $3.7-3.8 \%$ fat. In the elite farms and in those where the proper exploitation conditions are ensured, productions of over $4500 \mathrm{~kg}$ of milk/lactation are obtained.

Reproductive attributes. The reproduction process is a factor of particular importance in determining the efficiency of animal production. Thus, the reproduction process influences the rhythm of numerical augmentation and quality 
improvement of the bovine number, with direct effects on farm profitability.

The evaluation of reproductive efficiency in a cattle farm is synthetically assessed by calculating and analyzing breeding indexes. Reproduction indices allow permanent knowledge of the quality of reproduction activity and avoiding situations that can cause economic losses, and allows the preparation of business plans from different projects and feasibility studies for the farm development or the opening of financing and lending lines for agricultural activities (Onaciu, 2013). The main reproduction parameters monitorized in the study were: age of first calving, service-period, calving interval and natality.

\section{Material and methods}

For quantitative and qualitative determination of milk production in investigated cows, controls of milk production in three consecutive years were carried out periodically.

Official control of milkproduction performance was carried out in compliance with the control methodology regulated by the national legislation (OM 18/2006, 19/2006, with subsequent amendments and completions), legislation approved by the competent international body, namely the International Committee for Animal Recording (ICAR).

The control method used was AT 6 (the interval between controls was 42 days).

The cows subjected to the study were Romanian Bălțată breed, which had the general zooeconomic features presented in the specialized literature (Onaciu and Velea, 2002, Ujica et al., 2007, Acatincăi, 2010).

Investigations were made on 214 lactations from 214 Bălţată Românească cows from different lactations and ages from 16 respresentative exploitations from 3 counties (Alba, Bihor, Hunedoara) as follows:

Alba County - 7 farms with 80 cows

Bihor County - 4 farms with 69 cows

Hunedoara County - 5 farms with 65 cows

Because the number of cows on a farm does not allow an objective presentation of the productive potential according to the lactation status, we have opted for a presentation of the average of the lactate average of the herd studied at the level of each county.
The age at first calving (AFC) is expressed in months and is an individual or average synthetic indicator on the farm, calculated only heifers. It is recommended that the age at first calving to be 2527 months for the Bălțata Românească and Bruna breeds (Onaciu, 2013). The calculation for a single female is: $\mathrm{AFC}=\mathrm{AFI}+\mathrm{Dg}$;

AFI - age of first insemination

Dg - gestation duration.

Service-period (SP) is the time interval between last birth and the first fertilization fertile with the installation of gestation. This indicator may show normal values ranging from 60 to 115 days (Onaciu, 2013), with an optimal duration in cows of 45-90 days (Stanciu et al., 2005).

Calving interval (CI) is expressed in days and represents the period between two successive births, and must have values between 365 and 400 days. On this parameter, the natality is calculated. Calving interval is calculated only for second and later lactation cows.

Calculation for a single female: $\mathrm{CI}=\mathrm{Rg}+\mathrm{Dg}$

$\mathrm{Rg}$ - gestational rest

Dg - gestation duration

Mammary rest (MR) is minimum 6 weeks and is absolutely neccesar. The lesser the rest is (less than 6 weeks), or more than 8 weeks, the lower the milk production in the next lactation. This interval is determinant for the ability to maintain animal health.

Natality (N) is the technical reproductive index of the breeding function, calculated on the basis of the number of live and viable calves regardless of sex, obtained over a period of time (usually 365 days) from 100 heads, cows and heifers. The individual and average birth rates in the studied cows were calculated based on the length of the interval between the births: $\mathrm{N} \%=$ 365 / CI.

For the analysis of the main breeding indices, the data gathered through personal observations were used, which were supplemented both with the data from the primary records of the farms and with the artificial insemination operators' records.

In order to express the results of the research and to obtain precise data, a series of calculations were used which lead to the estimation of the variability. Arithmetic average, variance, standard deviation, standard error of a mean, variation coefficient, were the measures of central value of the data set. 
Table 2. Comparative results of the productive characteristics of cows studied in the Apuseni Mountains

\begin{tabular}{|c|c|c|c|c|c|c|}
\hline \multirow{2}{*}{ Lactation } & \multicolumn{2}{|c|}{$\begin{array}{l}\text { HUNEDOARA } \\
\text { County }\end{array}$} & \multicolumn{2}{|r|}{$\begin{array}{c}\text { ALBA } \\
\text { County }\end{array}$} & \multicolumn{2}{|r|}{$\begin{array}{l}\text { BIHOR } \\
\text { County }\end{array}$} \\
\hline & $\begin{array}{l}\text { Nr. } \\
\text { days }\end{array}$ & $\begin{array}{l}\text { Milk production } \\
\text { (l) / lactation }\end{array}$ & $\begin{array}{l}\text { Nr. } \\
\text { days }\end{array}$ & $\begin{array}{l}\text { Milk production } \\
\text { (l)/ lactation }\end{array}$ & $\begin{array}{l}\text { Nr. } \\
\text { days }\end{array}$ & $\begin{array}{l}\text { Milk production } \\
\text { (l) / lactation }\end{array}$ \\
\hline $1^{\text {st }}$ total lactation & 322.40 & 4073.80 & 318.750 & 3918.53 & 326.77 & 4233.50 \\
\hline $1^{\text {st }}$ standard lactation & 302.70 & 3921.62 & 302.310 & 3805.66 & 303.85 & 4076.14 \\
\hline $2^{\text {nd }}$ total lactation & 319.80 & 4429.59 & 330.310 & 4254.25 & 334.81 & 4543.82 \\
\hline $2^{\text {nd }}$ standard lactation & 303.13 & 4301.81 & 303.690 & 4053.20 & 304.24 & 4297.62 \\
\hline $3^{\text {rd }}$ total lactation & 329.11 & 4802.03 & 323.400 & 4492.58 & 329.64 & 4925.03 \\
\hline$\underline{3}^{\text {rd }}$ standard lactation & 304.00 & 4578.44 & 302.100 & 4314.97 & 303.36 & 4686.16 \\
\hline $4^{\text {th }}$ total lactation & 330.11 & 5141.98 & 318.060 & 4787.47 & 336.67 & 5244.65 \\
\hline $4^{\text {th }}$ standard lactation & 303.00 & 4893.81 & 300.940 & 4632.19 & 304.33 & 4942.03 \\
\hline$\geq 5^{\text {th }}$ total lactation & 327.73 & 5231.26 & 319.750 & 4913.71 & 334.83 & 5341.89 \\
\hline$\geq 5^{\text {th }}$ standard lactation & 304.18 & 5015.73 & 302.080 & 4764.43 & 304.11 & 5046.28 \\
\hline Average total lactation & 325.60 & 4796.40 & 321.360 & 4528.05 & 332.64 & 4815.26 \\
\hline Average standard lactation & 303.52 & 4605.23 & 302.150 & 4372.82 & 304.00 & 4569.17 \\
\hline
\end{tabular}

\section{Results and discussions}

Productive attributes. By analyzing the data obtained (Table 2) which render the characteristics of cows studied in the three Counties (Hunedoara, Alba and Bihor), for milk production, in the total lactation and standard lactatation for the number of studied cows, the following observations were made:

- $1^{\text {st }}$ lactation, average milk production per total lactation (322.4 days) was $4073.80 \mathrm{~kg}$ and on standard lactation (302.7 days) was $3921.62 \mathrm{~kg}$. - $2^{\text {nd }}$ lactation, the average milk production per total lactation (319.8 days) was $4429.59 \mathrm{~kg}$ and on standard lactation (303.1 days) was 4301.81 $\mathrm{kg}$.

- $3^{\text {rd }}$ lactation, the average milk production per total lactation (329.1 days) was $4802.03 \mathrm{~kg}$ and on standard lactation (304.0 days) was 4578.44 $\mathrm{kg}$.

- $4^{\text {th }}$ lactation, the average milk production per total lactation (330.1 days) was $5141.98 \mathrm{~kg}$ and on standard lactation (303.0 days) was 4893.81 $\mathrm{kg}$.

- $5^{\text {th }}$ lactation and above, average milk production per total lactation (327.73 days) was 5231.26 $\mathrm{kg}$ and on standard lactation (304.2 days) was $5015.73 \mathrm{~kg}$.

- Production over all lactations, mean milk production (325.6 days) was $4796.40 \mathrm{~kg}$, and standard lactation (303.5 days) was $4605.23 \mathrm{~kg}$.

Regarding the potential of the cows studied in Alba County, for the milk production, both total lactation and standard lactation, as well as the duration of lactation the following results were obtained:

- $1^{\text {st }}$ lactation, average milk production per total lactation (318.75 days) was $3918.53 \mathrm{~kg}$ and on standardlactation (302.31 days) was 3805.66 $\mathrm{kg}$.

- $2^{\text {nd }}$ lactation, the average milk production per total lactation (330.3 days) was $4254.25 \mathrm{~kg}$ and on standard lactation (303.69 days) was $4053.20 \mathrm{~kg}$.

- $3^{\text {rd }}$ lactation, the average milk production per total lactation (323.40 days) was $4492.58 \mathrm{~kg}$ and on standard lactation (302.10 days) was $4314.97 \mathrm{~kg}$.

- $4^{\text {th }}$ lactation, the average milk production per total lactation (318.06 days) was $4787.47 \mathrm{~kg}$ and on standard lactation (300.94 days) was $4632.19 \mathrm{~kg}$.

- $5^{\text {th }}$ lactation and above, average milk production per total lactation (319.75 days) was 4913.71 $\mathrm{kg}$ and on standard lactation (302.08 days) was $4764.43 \mathrm{~kg}$.

- total lactation production, a average milk production (321.36 days) was $4528.05 \mathrm{~kg}$, and for standard lactation (302.15 days) was $4372.82 \mathrm{~kg}$.

Analyzing the results obtained, it is found that the average milk production, both on total lactation and on standard lactation, as well as the lactation duration of the studied cow flock is within the limits of the Romanian Bălțata breed.

The characteristics for milk production in Bihor County, both on total lactation and on standard lactation, as well as the duration of 
Table 3. Comparative results of the reproductive characteristics of cows studied in three Counties from Apuseni Mountains (AFB - age first birth; MR - mammary rest; SP - service-period; CI calving interval)

\begin{tabular}{|c|c|c|c|c|}
\hline \multicolumn{5}{|c|}{ HUNEDOARA County } \\
\hline & AFB (days) & MR (days) & SP (days) & CI (days) \\
\hline Number of cows & 65 & 65 & 65 & 266 \\
\hline Average X & 878.1 & 56.7 & 96.9 & 400.8 \\
\hline Standard deviation & 90.44 & 9.97 & 23.81 & 36.04 \\
\hline Variation coefficient V\% & 10.30 & 17.58 & 24.55 & 8.99 \\
\hline Min. value & 632 & 40 & 37 & 321 \\
\hline Max. value & 1036 & 92 & 147 & 565 \\
\hline \multicolumn{5}{|c|}{ ALBA County } \\
\hline Number of cows & 80 & 80 & 80 & 302 \\
\hline Average $\mathrm{X}$ & 841.0 & 58.4 & 94.8 & 395.5 \\
\hline Standard deviation & 86.47 & 8.98 & 24.01 & 34.13 \\
\hline Variation coefficient V\% & 10.28 & 15.37 & 25.32 & 8.63 \\
\hline Min. value & 681 & 41 & 43 & 327 \\
\hline Max. value & 1084 & 90 & 148 & 504 \\
\hline \multicolumn{5}{|c|}{ BIHOR County } \\
\hline Number of cows & 69 & 69 & 69 & 214 \\
\hline Average X & 856.1 & 60.4 & 107.6 & 398.8 \\
\hline Standard deviation & 82.12 & 9.99 & 22.85 & 26.55 \\
\hline Variation coefficient V\% & 9.59 & 16.54 & 21,23 & 6.66 \\
\hline Min. value & 646 & 42 & 47 & 331 \\
\hline Max. value & 1034 & 90 & 167 & 512 \\
\hline
\end{tabular}

lactation together with the number of cows studied, lead to the following findings:

- $1^{\text {st }}$ lactation, average milk production per total lactation (326.7 days) was $4233.50 \mathrm{~kg}$, and on standard lactation (303.8 days) was $4076.14 \mathrm{~kg}$. - $2^{\text {nd }}$ lactation, average milk production per total lactation (334.8 days) was $4543.82 \mathrm{~kg}$, and on standard lactation (304.2 days) was $4297.62 \mathrm{~kg}$.

- $3^{\text {rd }}$ lactation, the average milk production per total lactation (329.6 days) was $4925.03 \mathrm{~kg}$ and on standard lactation (303.4 days) was 4686.16 $\mathrm{kg}$.

- $4^{\text {th }}$ lactation, the average milk production per total lactation (336.7 days) was $5244.65 \mathrm{~kg}$ and on standard lactation (304.3 days) was 4942.03 $\mathrm{kg}$.

- $5^{\text {th }}$ lactation and above, average milk production per total lactation (334.8 days) was 5341.89 $\mathrm{kg}$ and on standard lactation (304.1 days) was $5046.28 \mathrm{~kg}$.

- total milk production and lactation periods, average milk production per total lactation (332.6 days) was $4815.26 \mathrm{~kg}$ and per standard lactation (304.0 days) was $4569.17 \mathrm{~kg}$.

The obtained results, which reflects current milk production, shows that the studied herds have real production potential, average yields obtained for lactation and duration, placed in the upper limit of Romanian Bălțata race scale, according to specialized literature (Colceri et al., 2005, Crişan and Mureșan, 2007, Doliş et al., 2015, Cziszter et el. 2017).

Intensive farms have better productions reported (Neamţ et al. 2011, Hric and Pavlik, 2012), due to the intensive care programs and the following of way and quality of feeding.

Reproduction parameters. Analyzing the data presented in Table 3, which show the main breeding parameters on different lactations, we find the following values for Hunedoara County:

- Age at first calving (AFC) is expressed in days or months and is an individual or average synthetic indicator on the farm, calculated for heifers only. The number of cows studied was 878.1 days (28.8 months). This value is within normal limits but can be improved.

- Mammary rest (MR) is not considered a reproduction index, the importance of this period is technological and economic. The average duration of breast rest was 56.7 days.

- Service period (SP) or resting gestation, has an optimal duration for 60-115 days of cows. The total lactation service period in the studied population averaged 96.9 days. We consider 
that the service period under 115 days implies a good value of the birth rate above $91.0 \%$.

- Calving-interval (CI). Having the exact date of births, calving interval (CI) was calculated for the total studied population. Analyzing the interval between calving on total lactations, it can be stated that the average is 400.8 days, exceeding the normal limit (from 380 days). Exceeding the optimum value of this parameter indicates the existence of some small deficiencies in the breeding process.

- The individual and average birth rates of the studied groups were calculated based on the duration of the interval between litters. The value of this index averaged $91.1 \%$. This result shows good reproductive activity of the studied population.

Analyzing the data for Alba County cows, we note the following:

- The age at first calving (AFC) was 841.0 days (27.6 months). This value is within normal limits but can be improved.

- Mammary rest (MR) was 58.4 days.

- Service period (SP for total lactation period in the studied population had an average duration of 94.8 days.

- Calving-interval (CI) presented the average of 395.5 days, exceeding the normal limit (from 380 days).

- The individual and average birth rates index averaged $92.3 \%$. This result shows good reproductive activity of the studied population.

In Bihor County, the registered parameters were:

- The age at first calving was 856.1 days (28.1 months). This value is within normal limits but can be improved.

- Mammary rest (MR) was 60.4 days.

- Service period (SP) averaged for 107.6 days. We consider that the service value of the period under 115 days implies a good value of the birth rate above $91.00 \%$.

- Calving-interval (CI) have the average value of 398.8 days, exceeding the normal limit (from 380 days).

- The individual and average birth rates averaged 91.5\%. This result shows good reproductive activity of the studied population.

Different reproduction parameters and especially calving interval may be a useful measurement of fertility (Ball and Peters, 2004), and profitability measurement in dairy cattle herds. The obtained results are similar with different studies of other populations of dairy cows in Europe (Bujko et al., 2012, Riecka and Candrák, 2011, Ulutaş and Sezer, 2009)

\section{Conclusion}

Analyzing the data obtained regarding the average cow milk production, as well as the lactation duration in the three studied counties, it is found that on total lactation, the largest production was obtained in Bihor county with $4815.26 \mathrm{~kg}$ and 332.6 days, on standard lactation, Hunedoara County has the largest production with $4605.23 \mathrm{~kg}$ and 303.5 days).

The data obtained regarding the main breeding parameters in the studied farms, show that the average age at first calving was the lowest in the primary cows in Alba County (841.0 days), the average duration of breast rescue at the study was 56.7 days in Hunedoara County.

The studied population had an average service period of 94.8 days in Alba County, 96.9 days in Hunedoara County and 107.6 days in Bihor County and the calculated mean of the fertility interval in the studied population was 395.5 days in Alba County, 398.8 days in Bihor County and 400.8 days in Hunedoara County.

Breeding activity is good and can be improved. Due to the great importance of reproduction, for the productive performance of dairy farms, careful care and attention is needed for its planning and management.

\section{References}

1. Acatincăi S (2010). Tehnologia creșterii bovinelor. Agroprint Publishing House Timisoara.

2. Ball PJH, Peters AR (2004). Reproduction in cattle. $3^{\text {rd }}$ Edition: Blackwell Publishing 242 p.

3. Bujko J, Candrák J, Strapák P, Žitný J, Hrnčár C (2012). Evaluation of relationship between traits of milk production and reproduction traits in dairy cows of the Slovak spotted breed. Scientific Papers Faculty of Animal Science s and Biotechnologies, Timişoara, 45(1): 115-119.

4. Colceri D, Sonea C, Rebedea M, Ghiță E, Costache M (2005). Structura genetic a rasei bălțată cu negru românească probleme de actualitate şi perspectivă. Analele IBNA, 21: 112-119.

5. Crişan G, Mureșan G (2007). Research regarding the somatic cell count and the milk production for the Black-spotted cows. Lucrări Stiinţifice Zootehnie şi Biotehnologii, 40(2): 515-520. 
6. Cziszter LT, Ilie DE, Neamţ RI, Neciu FC, Săplăcan SI, Gavojdian D (2017). Comparative study on production, reproduction and functional traits between Fleckvieh and Braunvieh cattle. Asian-Australas Journal of Animal Science, 30(5):666-671.

7. Doliş L, Gâlcă I, Doliş M (2015). Research regarding production and reproductive traits on the first four lactation, in Romanian Black and White dairy cows. Lucrări ştiinţifice, Seria Zootehnie, 55: 191-195.

8. Fodor I, Ózsvári L (2015). The evaluation of reproductive performance in dairy herds. In: Proceedings of the 5th International Conference on Management 2015. Management, leadership and strategy for SMEs' competitiveness. Szent István University Publishing House, Gödöllő, 461-466. Indexes, Available online: https://www.wvu.edu/ agexten/forglvst/Dairy/dirm5. pdf

9. Hric P, Pavlik I (2012). Factors effecting of the milk production in select herd of Slovak spotted breed. Scientific Papers: Animal Sciences and Biotechnologies, 45(1): 185-188.

10. Neamţ RI, Cziszter LT, Neciu FC, Marinescu FC, Ilie DE, Liviu CI (2011). Study regarding milk production and days in milk in the Fleckvieh-Type Romanian spotted breed from S.C.D.C.B.Arad, Scientific Papers: Animal Scienc e and Biotechnologies, 44(2): 302-304.
11. Onaciu G, (2013). Cresterea bovinelor, vol I, Casa Cărții de Știință Publishing House, Cluj-Napoca.

12. Onaciu G, Velea C (2002). Evaluarea performanţelor productive la bovine. Casa Cărţii de Stiinţă Publishing House, Cluj-Napoca.

13. Riecka Z, Candrák J (2011). Analysis of relationship between production and reproduction triaits of Holstein cattle population in the Slovak Republic. Scientific Papers Faculty of Animal Sciences and Biotechnologies, Timişoara, 44(1): 332-336.

14. Stanciu G, Cziszter LT, Acatincăi S, Erina S (2005). Researches regarding the effect of crossbreeding the Red Holstein and Bălţata Românească breeds on the shape of the lactation curve. Lucrări ştiinţifice Zootehnie şi Biotehnologii, 38: 30-32.

15. Ujică V, Maciuc V, Nistor I (2007). Managementul creșterii vacilor de lapte. Alfa Publishing House, Iaşi.

16. Ulutaş Z, Sezer M (2009). Genetic study of milk production and reproduction traits of local born Simmental cattle in Turkey. Ziraat Facültesi Dergisi, 26(1): 53-59.

17. Verner MA, Majeskie JL, Garlichs SC (2012). Interpreting Reproductive Efficiency Indexes. In "Dairy Integrasted Reproductive Management" 